\title{
Estimation of Some Heavy Metals and Mineral Elements in Tissues of Oreochromis niloticus Collected from Goronyo Dam and its Two Tributaries inNorth-Western Sub-Sahara Nigeria
}

\author{
*Muhammad, H.L., ${ }^{1}$ Shehu, R.A., ${ }^{2}$ Bilbis, L.S. ${ }^{2}$ Dangoggo S.M ${ }^{3}$ \\ ${ }^{I}$ Department of Biochemistry, Federal University of Technology, Minna, Nigeria \\ ${ }^{2}$ Department of Biochemistry, Usmanu Danfodiyo University, Sokoto, Nigeria \\ ${ }^{3}$ Department of Applied Chemistry, Usmanu Danfodiyo University Sokoto, Nigeria
}

\begin{abstract}
The Nile TilapiaOreochromis niloticus(a fish species) was collected from Goronyo Dam, its two tributaries and Rima River(an overflow of Goronyo Dam) in two seasons for comparative studies of metal contents in gills, muscles and bones. The samples were dissected, organs were collected and digested by FAO/SIDA methods of 1983. Atomic Absorption Spectrophotometer(AAS) was used for the estimation of metals and mineral elements in the samples as described in the Pye Unican Atomic Absorption data book(1984). Only fishes collected in season II(August-September) of Goronyo Dam had lead $(\mathrm{Pb})$ values in gills, muscles and bones higher than theWorld Health Organizationstandard of $2.0 \mu \mathrm{g} / \mathrm{g}$ in sea foods. Oreochromis niloticus species of season II consumed from Goronyo Dam can be a rich source of Pb to humans.
\end{abstract}

Keywords: Oreochromis niloticus, Heavy metals, Lead, Cadmium, Goronyo Dam

\section{Introduction}

Human beings have been exposed to heavy metal toxins for an immeasurable amount of time. The domestic and industrial activities of human result in the production of materials, which are disposed of into theenvironment. These materials contain heavy metal toxins which accumulate faster in the body than can be eliminated (Goyer, 1991). All these contribute to human physiological and psychological decline (Kiffhey and Clement, 1994). The heightened concern for reduction of environmental pollution that has been occurring over the past $20-25$ years has stimulated active continuing research on the toxicology of heavy metals. While the toxic effects of these substances are a widespread concern in the modern industrial context,the humansociety has succeeded in poisoning itself with them repeatedly throughout recorded history. All ecosystems are affected by ubiquitous atmospheric deposition of organic and inorganic pollutants such as heavy metals (Reddy et al., 1995). Today heavy metals are (abundant) in the drinking water, air and soil due tohuman's increased use of products containing these compounds. They are present in virtually every area of modern consumerism - from construction materials to cosmetics, medicines to processed foods, fuel sources to agents of destructive appliances and personal care products (Largewerff, 1972). Human population growth and technological advancement have contributed to increased complexity in types and amount of waste materials, which enter the ecosystems as products or by-productsof industrial processes (Stewart et al., 1974). It is very difficult for anyone to avoid exposure to any of the many harmful heavy metals that are so prevalent in the environment. Oreochromis niloticusis, one of the major fish species consumed by people living around the study areas, some of it is also exported to the neighbouring Niger Republic.Heavy metals originate within the earth where they may be harmless until released by human interference. As the concentrations of heavy metals rise in the air, water and topsoil, they also rise within human bodies contributing to chronic diseases, learning disorders, cancer and premature aging (Keen et al., 1981). Once in the body, they compete with and displace the essential minerals such as zinc, copper, manganese and calcium and bind their receptor sites causing diffuse symptoms by affecting nerves, hormones, digestion and immune functions. In general, heavy metals produce their toxicities by forming complexes or ligands with other organic compounds. These modified biological molecules loose their ability to function properly, and result in malfunction or death of the affected cells (Mouvet, 1984). The most important common elements involved in ligand formation are oxygen, sulphur and nitrogen. When metals bind to these groups they inactivate important enzyme systems, or affect protein structure. The degree to which a system, organ, tissue or cell is affected by a heavy metal toxin depends on the toxin itself and the individual's degree of exposure.Overtime, there have been continuousactivities involving illegal mining of gold, and the dyeing of clothing materials by the community of the study area. The gold mining activity generates lead as a by-product because lead is found in combination with gold as ore. The dyeing of materials on the other hand makes use of chemical agents that are toxic to aquatic organisms at certain concentrations. The two activities produce effluents which get into the aquatic environment either by direct disposition or by run-offduring rain fall. 


\section{The Study Area}

The Goronyo Dam is located near Keta village, some twenty five kilometres east of Goronyo town and ninety kilometres away from Sokoto town, in north-western region of Nigeria. The construction of the earth fill dam was completed across the Rima River in 1984, and has Gagare, Bunsuru and Maradi rivers as the main tributaries. The river Gagare comes from Kaura Namoda through Moriki to Birnin Yero in Katsina State. River Bunsuru on the other hand comes from Zurmi in Zamfara State through Bafarawa. Both rivers (Gagare and Bunsuru) have their confluence at Attalawa. Active fishing activities are going on in the two tributaries. The dam is made up of three embankments (main dam, secondary dam and saddle dam) with a reservoir area of 200 $\mathrm{km}^{2}$ and capacity of 942 million cubic meters at 288 meters above sea level (M.A.S.L) full storage. The dam supplies raw water for Sokoto State Water Board, stream bank (Fadama) irrigation through lifting, Wurno and Falalia irrigation schemes and fishing activities. Some of the crops grown by these schemes are rice, cassava, vegetables and garlic. River Rima is an overflow of Goronyo Dam, active fishing activities are taking place in all the rivers, and the river waters are also for irrigation.The study area (comprising Sokoto, Zamfara, and Katsina states), is a semi-arid region with moderate rain fall, and all the weathers at the extreme. It was speculated that the mining activities might generate lead which may probably be held in drainages (if at all there are any), or the by-products may just be in the air and the immediateenvironment, and will likely be washed away into the aquatic environment during rain fall.Dry season is termed season 1 (January-February) while rainy season is termed season 11 (August-September).

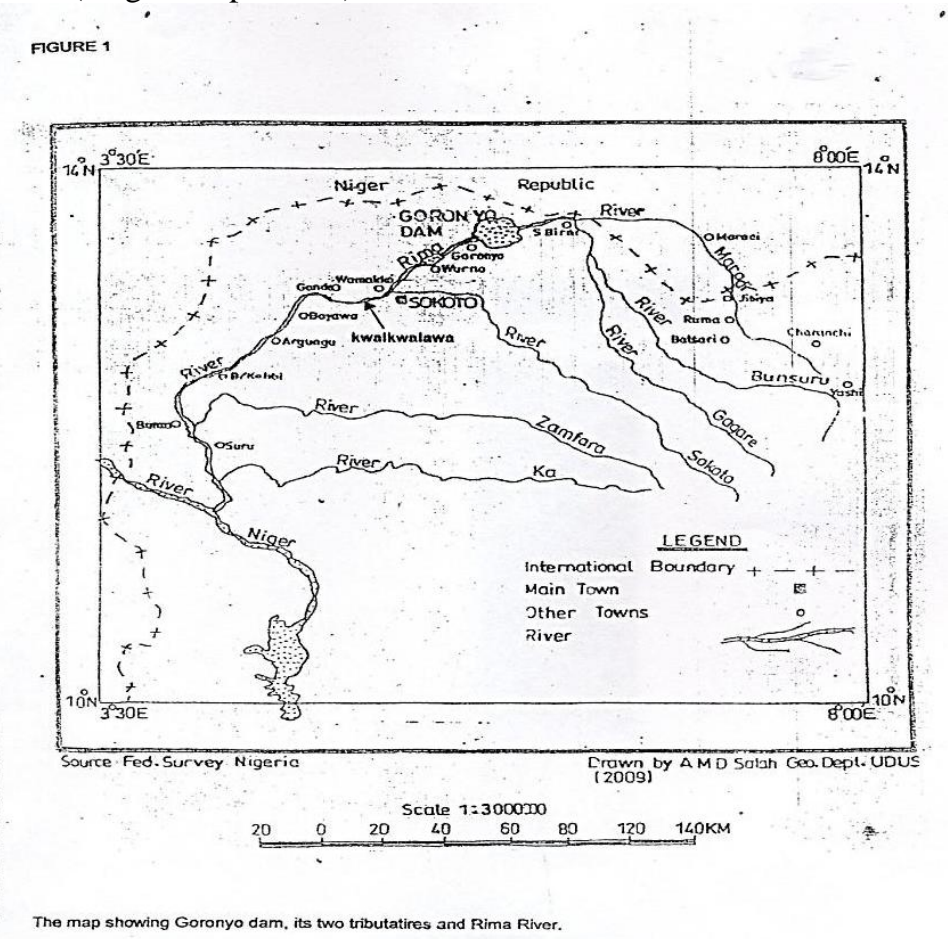

It was in Zamfara state, Anka local government area that lead poisoning of children numbering over 600 took place between the year 2010and 2011 WHO (2011). Lead was taken into various homes by illegal gold miners where their wives do the final processing of the ore to obtain the pure gold for onward transportation to the market to be sold to gold dealers. Lead poisoning took place because the villagers used same containers for processing the ore and for other domestic activities. Children were especially more vulnerable because the blood-brain barrier is still at the process of formation.

\section{Chemicals and Reagents}

\section{Materials And Methods}

All chemicals and reagents used for this work are of analytical grade. They include: concentrated $\mathrm{HNO}_{3}, \mathrm{H}_{2} \mathrm{O}_{2}, \mathrm{H}_{2} \mathrm{SO}_{4}, 0.01 \mathrm{M} \mathrm{CaCl}, \mathrm{MnSo}_{4} .4 \mathrm{H}_{2} \mathrm{O}$, flouroboric acid, starch solution, $0.025 \mathrm{M} \mathrm{Na}_{2} \mathrm{~S}_{2} \mathrm{O}_{3} .5 \mathrm{H}_{2} \mathrm{O}$ (sodium thiosulphate), $25 \%(\mathrm{v} / \mathrm{v})$ acetic anhydride, glacial acetic acid, absorption grade lanthanum oxide, dry $\mathrm{NaCl}$, dry $\mathrm{KCl}$, pH buffer, dry calcium carbonate, concentrated $\mathrm{HCl}, \mathrm{HClO}_{4}$, lead metal, nickel metal, calcium metal, iron fillings, chromium metal, copper metal, magnesium ribbon, $\mathrm{NaN}_{3}, \mathrm{KI}$, and $40 \%(\mathrm{v} / \mathrm{v})$ hydrofluoric acid 


\section{Sample Collection}

Fresh specimens of Oreochromis niloticusweighing between $400 \mathrm{~g}$ - 700 gwere collected in the years 2005 and 2006as part of Ph.D research work from the local fishermen either at the time of fishing operations or as the fishermen landed on the shores.Five specimens were collected for each analysis. The fishes were kept in ice packed container for transportation to the laboratory where they were kept in the refrigerator till ready for digestion. Five tissues of gills, muscles and bones collected from eachof the five specimens were digested for analysis.

\section{Sample Digestion}

$2.0 \mathrm{~g}$ (wet weight), each of gills, muscles, or bones were separately placed in respectively labelled reflux flasks. $20 \mathrm{ml}$ of freshly prepared $(1: 1) \mathrm{HNO}_{3} / \mathrm{H}_{2} \mathrm{O}_{2}$ was added to each reflux flask in the block digestor for two hours till volumes reduced to about $10 \mathrm{ml}$. The digest was allowed to cool and filtered through Whatmann no 1 filter paper, and the volume made up to $100 \mathrm{ml}$. The digest was further transferred to polythene bottle and stored till ready for use (FAO/SIDA,1993).These tissues were chosen for analyses because they are the parts mostly consumed by the people living in the study areas, and man is the ultimately end receptor of the heavy metal being at the top of the trophic level in food chain.

\section{Estimation of Metals}

Atomic Absorption Spectrophotometer (Philips model PU 9100) was used for the estimation of $\mathrm{Pb}, \mathrm{Cd}$, $\mathrm{Cr}, \mathrm{Ni}, \mathrm{Fe}, \mathrm{Mg}, \mathrm{Ca}, \mathrm{Cu}, \mathrm{Na}$ and $\mathrm{K}$ as described in the Pye Unican Atomic Absorption data book (1984), and in the introduction to Atomic Absorption Spectrophotometry Scientific Analytical Equipment manual book by Whiteside (1987).

\section{Results}

The results of metal analyses in tissues of Oreochromis niloticus collected from the study sites are presented in Tables 1- 4. With the exception of Goronyo Dam with season 11 lead $(\mathrm{Pb})$ values in high concentrations above the World Health Organization(WHO) acceptable limit in sea foods, all other sites had values bellow the WHO limits. All the values reported aremeans of triplicate analyses of five specimens of gills, muscles, and bones from five samples of Oreochromis niloticus,results expressed as means with standard deviations. The data were statistically analysed using ANOVA with multiple comparisons. $\mathrm{P}<0.05$ were considered significant (Duncan et al., 1997).

TABLE 1

Metal concentrations $(\mu \mathrm{g} / \mathrm{g})$ in Oreochromisniloticus Tissues of River Bunsuru

\begin{tabular}{|c|c|c|c|c|c|c|c|c|c|c|c|}
\hline $\begin{array}{l}\text { Seas } \\
\text { on I }\end{array}$ & $\begin{array}{l}\text { Tiss } \\
\text { ue }\end{array}$ & $\mathbf{P b}$ & Cd & $\mathrm{Ni}$ & $\mathrm{Fe}$ & Mg & $\mathrm{Cr}$ & $\mathrm{Cu}$ & $\mathrm{Ca}$ & $\mathrm{Na}$ & $\mathbf{K}$ \\
\hline & Gills & $0.33^{a} \pm$ & $0.38^{\mathrm{a}} \pm$ & $0.34^{a} \pm 0$ & $33.02^{\mathrm{a}} \pm$ & $35.65^{a} \pm$ & $0.28^{\mathrm{a}} \pm$ & $1.13^{\mathrm{a}} \pm$ & $134.11^{a} \pm$ & $3.45^{\mathrm{a}} \pm$ & $3.48^{\mathrm{a}} \pm$ \\
\hline & & 0.05 & 0.12 & .05 & 2.80 & 6.23 & 0.07 & 0.01 & 6.88 & 0.60 & 0.33 \\
\hline & Mus & $0.31^{\mathrm{a}} \pm$ & $0.37^{\mathrm{a}} \pm$ & $0.34^{a} \pm 0$ & $32.46^{b}=$ & $34.36^{b}=$ & $0.29^{\mathrm{a}} \pm$ & $2.12^{b} \pm$ & $132.16^{b} \pm$ & $3.63^{\mathrm{a}} \pm$ & $3.59^{\mathrm{a}} \pm$ \\
\hline & cles & 0.03 & 0.11 & .05 & 3.28 & 6.22 & 0.07 & 0.01 & 8.47 & 0.54 & 0.34 \\
\hline & Bone & $0.32^{\mathrm{a}} \pm$ & $0.37 \pm$ & $0.33^{a} \pm 0$ & $32.03 \pm \pm$ & $35.14^{\mathrm{a}} \pm$ & $0.30^{\mathrm{a}} \pm$ & $1.14^{\mathrm{a}} \pm$ & $138.86^{\circ} \pm$ & $3.366^{\mathrm{a}} \pm$ & $3.76^{\mathrm{a} \pm}$ \\
\hline & $\mathrm{s}$ & 0.04 & 0.11 & .05 & 2.54 & 6.32 & 0.06 & 0.01 & 5.42 & 0.52 & 0.43 \\
\hline \multirow{8}{*}{$\begin{array}{l}\text { Seas } \\
\text { on } \\
\text { II }\end{array}$} & & & & & & & & & & & \\
\hline & & & & & & & & & & & \\
\hline & \multirow[t]{2}{*}{ Gills } & $0.04^{a_{ \pm}}$ & $0.03^{a_{4}}$ & $0.01 \mathrm{a} \pm 0$ & $30.27^{a} \pm$ & $70.16^{\mathrm{a}} \pm$ & $0.13^{a} \pm$ & $2.18^{\mathrm{a}} \pm$ & $144.87^{a} \pm$ & $3.42^{\mathrm{a}} \pm$ & $2.92^{\mathrm{a}_{ \pm}}$ \\
\hline & & 0.02 & 0.02 & .005 & 2.28 & 5.82 & 0.06 & 0.11 & 7.18 & 0.36 & 0.37 \\
\hline & Mus & $0.02^{\mathrm{a}_{4}}$ & $0.03^{a_{4}}$ & $0.03^{a} \pm 0$ & $40.90^{b} \pm$ & $73.74^{b} \pm$ & $0.13^{a} \pm$ & $1.18^{b} \pm$ & $132.45^{b} \pm$ & $2.99^{b} \pm$ & $2.45^{\mathrm{a}} \pm$ \\
\hline & cles & 0.01 & 0.02 & .02 & 3.88 & 4.27 & 0.09 & 0.12 & 5.99 & 0.54 & 0.35 \\
\hline & Bone & $0.02^{\mathrm{a}} \pm$ & $0.06^{b} \pm$ & $0.05^{b} \pm 0$ & $20.90^{\circ} \pm$ & $53.86^{\circ} \pm$ & $0.06^{b} \pm$ & $1.23^{b} \pm$ & $146.65 c^{\circ}$ & $3.06 c_{ \pm}$ & $3.82^{b} \pm$ \\
\hline & s & 0.02 & 0.02 & .46 & 3.70 & 14.61 & 0.04 & 0.11 & 13.70 & 0.63 & 0.33 \\
\hline
\end{tabular}

Season I (January- February)

Season II (August - September)

Metal concentrations are compared among tissues within each season

ANOVA was used for data generated

$\mathrm{a}=$ means on the same column, with same superscripts are not significantly different $(\mathrm{P}>0.05)$

$\mathrm{b}, \mathrm{c}=$ means on the same column, with different superscripts differ significantly $(\mathrm{P}<0.05)$ 
TABLE 2

Metal concentrations $(\mu \mathrm{g} / \mathrm{g})$ in Oreochromisniloticus Tissues of River Gagare

\begin{tabular}{|c|c|c|c|c|c|c|c|c|c|c|c|}
\hline $\begin{array}{l}\text { Seas } \\
\text { on I }\end{array}$ & $\begin{array}{l}\text { Tissu } \\
\mathrm{e}\end{array}$ & $\mathrm{Pb}$ & $\mathrm{Cd}$ & $\mathrm{Ni}$ & $\mathrm{Fe}$ & $\mathrm{Mg}$ & $\mathrm{Cr}$ & $\mathrm{Cu}$ & $\mathrm{Ca}$ & $\mathrm{Na}$ & $\bar{K}$ \\
\hline & Gills & $0.23^{a} \pm 0$ & $0.15^{a} \pm 0$ & $0.18 \geq \geq 0$ & $47.56^{a}=3$ & $26.96 \pm \pm 5$ & $0.27 a=0$ & $1.60^{a} \pm 0$ & $254.93 \mathrm{a}=1$ & $4.35 \mathrm{a}=0$ & $2.99 \mathrm{a}=0$ \\
\hline & & .04 & .02 & .02 & 73 & .75 & .09 & .10 & 2.18 & .52 & .71 \\
\hline & Musc & $0.24^{a} \pm 0$ & $0.14^{a}=0$ & $0.18 \mathrm{a}=0$ & $43.75^{b} \pm 6$. & $26.52 \mathrm{~s}=3$ & $0.30 \mathrm{a}=0$ & $2.40^{b}=0$ & $234.81^{b} \pm 1$ & $2.97^{b}=0$ & $3.27^{b}=0$ \\
\hline & & .06 & .02 & .02 & 33 & .28 & .10 & .11 & 2.34 & .42 & .68 \\
\hline & Bone & $0.28^{b}=0$ & $0.94^{b}=0$ & $0.17 \mathrm{a}=0$ & $55.38 c \pm 1$ & $24.11^{b}=$ & $0.26 \mathrm{a}=0$ & $3.70= \pm 0$ & $268.07 \bullet \pm 1$ & $3.18 c=0$ & $3.05 \mathrm{~s}=0$ \\
\hline & s & .06 & .35 & .02 & 1.28 & 6.32 & .08 & .10 & 3.02 & .66 & .38 \\
\hline \multicolumn{12}{|l|}{$\begin{array}{l}\text { Seas } \\
\text { on II }\end{array}$} \\
\hline & Gills & $0.38 \mathrm{a}=0$ & $0.40^{a} \pm 0$ & $0.36 \mathrm{~s}=0$ & $30.37 a \pm 2$ & $42.59 \mathrm{a} \pm 1$ & $0.37: \pm 0$ & $1.06 \mathrm{~s}=0$ & $275.39 a \pm 2$ & $3.78 \mathrm{a}=0$ & $2.89 \mathrm{a}=0$ \\
\hline & & .17 & .11 & .12 & 53 & .67 & .18 & .03 & 5.69 & .48 & .38 \\
\hline & Musc & $0.23^{b}=0$ & $0.17^{b}=0$ & $0.24^{b} \pm 0$ & $30.90 \mathrm{a}=3$ & $58.02^{b}=$ & $0.33^{b}=0$ & $1.10^{a}=0$ & $254.09 b \pm 2$ & $3.96 \mathrm{~s}=0$ & $3.28^{b}=0$ \\
\hline & les & .18 & .08 & .05 & 84 & 6.74 & .15 & .03 & 0.36 & .78 & .40 \\
\hline & Bone & $0.27 c=0$ & $0.17^{b}=0$ & $0.32 s=0$ & $30.94^{a} \pm 3$ & $58.52^{\mathrm{b}}=$ & $0.32^{b} \pm 0$ & $1.09 \mathrm{a}=0$ & $203.01^{\circ} \pm 2$ & $3.65 \mathrm{a}=0$ & $3.51^{\circ}=0$ \\
\hline & $\mathrm{s}$ & .05 & .04 & .08 & 33 & 8.81 & .11 & .03 & 6.84 & .27 & .65 \\
\hline
\end{tabular}

Season I (January- February)

Season II (August - September)

Metal concentrations are compared among tissues within each season

ANOVA was used for data generated

$\mathrm{a}=$ means on the same column, with same superscripts are not significantly different $(\mathrm{P}>0.05)$

$\mathrm{b}, \mathrm{c}=$ means on the same column, with different superscripts differ significantly $(\mathrm{P}<0.05)$

TABLE 3

Metal concentrations $(\mu \mathrm{g} / \mathrm{g})$ in Oreochromisniloticus Tissues of River Rima

\begin{tabular}{|c|c|c|c|c|c|c|c|c|c|c|c|}
\hline $\begin{array}{l}\text { Seas } \\
\text { on I }\end{array}$ & $\begin{array}{l}\text { Tiss } \\
\text { ue }\end{array}$ & $\mathbf{P b}$ & $\mathrm{Cd}$ & $\mathbf{N i}$ & $\mathrm{Fe}$ & Mg & $\mathrm{Cr}$ & $\mathrm{Cu}$ & $\mathrm{Ca}$ & $\mathrm{Na}$ & $\mathbf{K}$ \\
\hline & Gills & $0.12^{\mathrm{a}} \pm$ & $0.32^{\mathrm{a}} \pm$ & $0.10^{\mathrm{a}} \pm$ & $45.89^{\mathrm{a}} \pm$ & $23.55^{\mathrm{a}} \pm$ & $0.11^{\mathrm{a}} \pm$ & $3.20^{\mathrm{a}} \pm$ & $164.64^{\mathrm{a}} \pm$ & $5.33^{\mathrm{a}} \pm$ & $4.67^{\mathrm{a} \pm}$ \\
\hline & & 0.10 & 0.18 & 0.03 & 8.35 & 4.80 & 0.02 & 0.06 & 20.63 & 1.37 & 0.78 \\
\hline & Musc & $0.08^{b} \pm$ & $0.11^{b} \pm$ & $0.10^{\mathrm{a}} \pm$ & $38.00^{b} \pm$ & $20.73^{b} \pm$ & $0.12^{\mathrm{a}} \pm$ & $3.20^{\mathrm{a}} \pm$ & $136.31^{b} \pm$ & $4.51^{b} \pm$ & $4.35^{b} \pm$ \\
\hline & & 0.06 & 0.06 & 0.03 & 7.86 & 3.12 & 0.02 & 0.06 & 16.33 & 0.86 & 1.07 \\
\hline & Bone & $0.07^{b} \pm$ & $0.08 c_{ \pm}$ & $0.10^{\mathrm{a}} \pm$ & $29.57 c_{ \pm}$ & $19.85^{b} \pm$ & $0.11^{\mathrm{a}} \pm$ & $3.11^{\mathrm{a}} \pm$ & $205.33{ }^{c} \pm$ & $6.83 c_{ \pm}$ & $5.47^{\circ} \pm$ \\
\hline & s & 0.03 & 0.04 & 0.04 & 2.72 & 2.70 & 0.03 & 0.03 & 22.46 & 1.33 & 1.08 \\
\hline \multirow[t]{7}{*}{$\begin{array}{l}\text { Seas } \\
\text { on } \\
\text { II }\end{array}$} & & & & & & & & & & & \\
\hline & \multirow[t]{2}{*}{ Gills } & $0.08^{a} \pm$ & $0.11^{\mathrm{a}} \pm$ & $0.16^{\mathrm{a}} \pm$ & $30.47^{a} \pm$ & $60.05^{a} \pm$ & $0.24^{\mathrm{a}_{ \pm}}$ & $1.05^{\mathrm{a}} \pm$ & $208.28^{a} \pm$ & $3.24^{\mathrm{a}_{ \pm}}$ & $4.03^{a} \pm$ \\
\hline & & 0.05 & 0.11 & 0.03 & 2.60 & 9.07 & 0.10 & 0.03 & 18.29 & 0.15 & 0.14 \\
\hline & Musc & $0.13^{b} \pm$ & $0.10^{\mathrm{a}} \pm$ & $0.14^{\mathrm{a}} \pm$ & $30.13^{\mathrm{a}} \pm$ & $50.08^{b} \pm$ & $0.29^{\mathrm{a}_{4}}$ & $1.04^{a} \pm$ & $113.28^{\mathrm{b}} \pm$ & $3.18^{\mathrm{a}} \pm$ & $3.14^{b} \pm$ \\
\hline & les & 0.03 & 0.10 & 0.01 & 3.78 & 7.13 & 0.15 & 0.02 & 3.75 & 0.24 & 0.33 \\
\hline & Bone & $0.11^{\mathrm{a}} \pm$ & $0.09^{a_{ \pm}}$ & $0.22^{b} \pm$ & $30.31^{\mathrm{a}} \pm$ & $59.39^{\circ} \pm$ & $0.37^{b} \pm$ & $1.04^{\mathrm{a}_{ \pm}}$ & $165.75^{\circ} \pm$ & $3.15^{\mathrm{a}} \pm$ & $3.90^{\circ} \pm$ \\
\hline & $\mathrm{s}$ & 0.03 & 0.09 & 0.04 & 3.69 & 8.82 & 0.13 & 0.02 & 16.89 & 0.29 & 0.39 \\
\hline
\end{tabular}

Season I (January- February)

Season II (August - September)

Metal concentrations are compared among tissues within each season

ANOVA was used for data generated

$\mathrm{a}=$ means on the same column, with same superscripts are not significantly different $(\mathrm{P}>0.05)$

$\mathrm{b}, \mathrm{c}=$ means on the same column, with different superscripts differ significantly $(\mathrm{P}<0.05)$ 
TABLE 4

Metal concentrations ( $\mu \mathrm{g} / \mathrm{g})$ in Oreochromisniloticus Tissues of Goronyo Dam

\begin{tabular}{llllllllllll}
\hline $\begin{array}{l}\text { Seas } \\
\text { on I }\end{array}$ & $\begin{array}{l}\text { Tiss } \\
\text { ue }\end{array}$ & $\mathbf{P b}$ & $\mathbf{C d}$ & $\mathbf{N i}$ & $\mathbf{F e}$ & $\mathbf{M g}$ & $\mathbf{C r}$ & $\mathbf{C u}$ & $\mathbf{C a}$ & $\mathbf{N a}$ & $\mathbf{K}$ \\
\hline & Gills & $0.07^{\mathrm{a}} \pm$ & $0.02^{\mathrm{a}} \pm 0$ & $0.09^{\mathrm{a}} \pm 0$ & $33.28^{\mathrm{a}} \pm$ & $20.03^{\mathrm{a}} \pm$ & $0.17^{\mathrm{a}} \pm$ & $2.08^{\mathrm{a}} \pm$ & $128.97^{\mathrm{a}} \pm$ & $21.56^{\mathrm{a}} \pm$ & $12.97^{\mathrm{a}} \pm$ \\
& & 0.03 & .002 & 04 & 2.45 & 2.21 & 0.02 & 0.03 & 3.54 & 3.18 & 0.71 \\
& Mus & $0.06^{\mathrm{a}} \pm$ & $0.01^{\mathrm{a}} \pm 0$ & $0.08^{\mathrm{a}} \pm 0$. & $29.08^{\mathrm{b}} \pm$ & $17.44^{\mathrm{b}} \pm$ & $0.12^{\mathrm{b}} \pm$ & $2.07^{\mathrm{a}} \pm$ & $115.25^{\mathrm{b}} \pm$ & $18.04^{\mathrm{b}} \pm$ & $11.96^{\mathrm{b}} \pm$ \\
& cles & 0.03 & .002 & 04 & 1.97 & 1.81 & 0.02 & 0.03 & 3.17 & 2.24 & 0.47 \\
& Bone & $0.07^{\mathrm{a}} \pm$ & $0.02^{\mathrm{a}} \pm 0$ & $0.09^{\mathrm{a}} \pm 0$. & $21.60^{c^{a}} \pm$ & $14.74^{\mathrm{c}} \pm$ & $0.16^{\mathrm{a}} \pm$ & $2.07^{\mathrm{a}} \pm$ & $154.66^{\mathrm{c}} \pm$ & $18.02^{\mathrm{b}_{ \pm}}$ & $12.03^{\mathrm{a}_{ \pm}}$ \\
& $\mathrm{s}$ & 0.03 & .003 & 05 & 0.85 & 1.63 & 0.04 & 0.02 & 7.05 & 2.33 & 0.42 \\
\hline
\end{tabular}

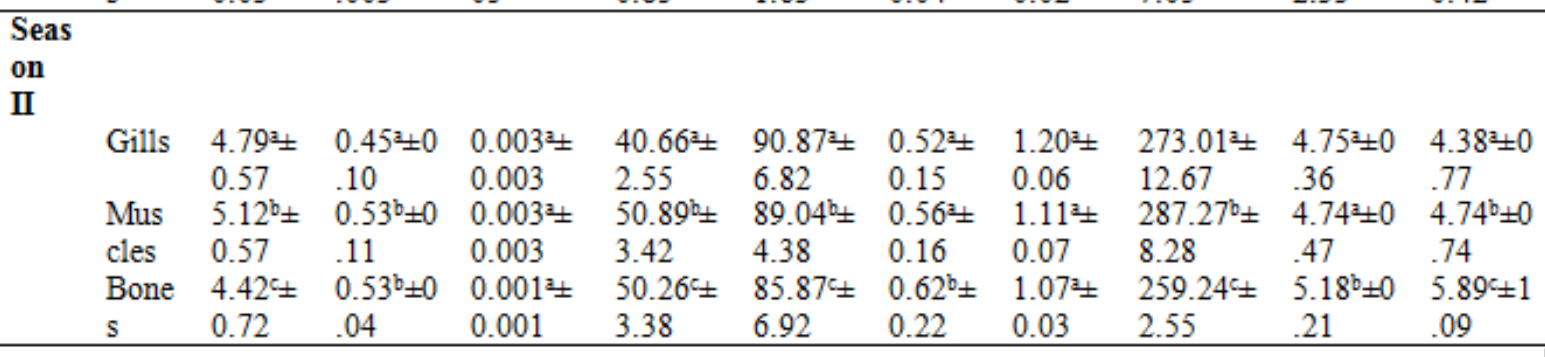

Season I (January- February)

Season II (August - September)

Metal concentrations are compared among tissues within each season

ANOVA was used for data generated

$\mathrm{a}=$ means on the same column, with same superscripts are not significantly different $(\mathrm{P}>0.05)$

$\mathrm{b}, \mathrm{c}=$ means on the same column, with different superscripts differ significantly $(\mathrm{P}<0.05)$

\section{Discussion}

The increasing concern with the roles and fates of heavy metals in Nigerian environment and their implication forhuman health has stimulated this work. There is little information on the concentrations of these metals in various locations where the samples were collected. There was also a remarkable case of lead poisoning of illegal gold miners and their families in Anka Local Government Area of Zamfara State, Nigeria (FMH, 2010). Elevated levels of some of the heavy metals in the aquatic environment can be a good indicator ofhuman-induced pollution (Davies et al., 1991). The discharge of heavy metals into rivers by domestic and industrial activities promoted their rapid association with particulates and incorporation in bottom sediments. And because of the bottom feeding habits ofsome fish species, including the Nile Tilapia,high levels are sometimes observed in fish tissues. The concentration of heavy metals, particularly $\mathrm{Pb}$, may exceed the maximal permissible concentration of $2.0 \mu \mathrm{g} / \mathrm{g}$ recommended in fresh sea foods by the WHO. Oreochromis niloticustissues bioccumulated high levels of $\mathrm{Pb}$ during the rainy season sampling of Goronyo Dam (Table 4).No tissue(gills, muscles and bones) presented Cd concentrationhigher than the WHO standard of $2.0 \mu \mathrm{g} / \mathrm{g}$. Since $\mathrm{Cd}$, like $\mathrm{Pb}$ plays no role in enzyme activities, chronic discharge of $\mathrm{Cd}$ containing wastes to aquatic environment over time will lead to bioaccumulation. Whenever this happens, $\mathrm{Cd}$ replaces $\mathrm{Zn}$ in $\mathrm{Zn}$ binding proteins. $\mathrm{Zn}$ and $\mathrm{Cd}$ are in the same group on the periodic table, have the same common oxidation state $(+2)$, and when ionized are almost of the same size. Due to these similarities, Cd readily replaces $\mathrm{Zn}$ in many biological systems, in particular, sulphur ligands. $\mathrm{Cd}$ can bind up to ten times more strongly than $\mathrm{Zn}$ in biological systems. $\mathrm{Cd}$ can also replace $\mathrm{Mg}$ and $\mathrm{Ca}$ in biological systems, although these replacements are rare (Lane and Morel, 2000). The metal - $\mathrm{Cu}$, though required for some enzyme activities can be toxic at high concentrations. It is however present bellow the WHO standard of $3.0 \mu \mathrm{g} / \mathrm{g}$ (except for dry season sampling of Rima River). $\mathrm{Cu}$, in its ionic forms $\mathrm{Cu}^{2+}, \mathrm{CuOH}_{2}{ }^{2+}$ and $\mathrm{CuOH}^{+}$are toxic to fish (Moore, 1991). The metals $\mathrm{Ni}$, $\mathrm{Fe}, \mathrm{Mg}, \mathrm{Cr}, \mathrm{Ca}, \mathrm{Na}$, and $\mathrm{K}$ are mineral elements and were present at tolerable limits and so do not cause threats to aquatic environment.BecauseOreochromis niloticus gills, muscles, and boneshad high levels of $\mathrm{Pb}$ in Goronyo Damin the rainy season (as shown in Table4), fishes consumed from this dam can be very rich source of $\mathrm{Pb}$. $\mathrm{Pb}$ interferes with several enzymes in the haem pathway and decreases haem biosynthesis by decreasing $\alpha$-aminolevulinic acid ferrochalatase activity. $\mathrm{Pb}$ is also sulphur seeking and easily bind to $\mathrm{S}-\mathrm{CH}_{3}$ and $\mathrm{S}-\mathrm{H}$ (sulphydryl groups) in enzyme protein (Venugopal and Luckey, 1975). Such immobilized enzymes cannot function properly. In general, differential levels of heavy metals in different tissues may be attributed to some biological factors: nature of the body covering with respect to penetrability, availability of right type of enzymes and optimal physicochemical conditions, excretory capacity and the rate of elimination of by-products of metabolism, availability of body size and the sensitivity of the site of action, body size, age and life cycle stage as well as ecology with particular reference to location ( Don-Pedro, 1997). Cadmium levels in the three organs 
analysed fromOreochromis niloticus from all the study areas and for both seasons did not exceed the WHO standard of $2.0 \mu \mathrm{g} / \mathrm{g}$.

Baron (1995) views bioaccumulation as a result of the competing rate of a chemical uptake and elimination. Thus, bioaccumulation may likely occur if the fish is able tocontinuously absorb the metals from the surrounding aquatic environment. As with $\mathrm{Pb}, \mathrm{Cd}$ plays no role in metabolism, but it is also sulphur-seeking. It binds to $\mathrm{S}-\mathrm{CH}_{3}$ and $\mathrm{S}-\mathrm{H}$ groups in enzymes proteins. $\mathrm{Cd}^{2+}$ andZn ${ }^{2+}$ are similar in their chemical properties including size. $\mathrm{Cd}^{2+}$ replaces $\mathrm{Zn}^{2+}$ in enzymes that contain the latter. It has been observed that Cd-Containing enzymes do not perform the same function as $\mathrm{Zn}$-containing enzymes. Presence of $\mathrm{Cd}$ in tissues when bound to metallothioneins allows it to be transported to the blood by the erythrocyte or bound to large muscular weight proteins (Nordberg, 1972).In contrast to $\mathrm{Pb}$ and $\mathrm{Cd}, \mathrm{Ni}$ and $\mathrm{Cu}$ are essential for enzyme activities. Ni is essential particularly in urease and dehydrogenase activities, absence of which retards growth or cause the death of the living organism. $\mathrm{Ni}$ is highly tolerable by organisms except the divalent state $\mathrm{Ni}^{2+}$ (Weast, 1998 ). $\mathrm{Ni}$ has been found to be bioavailable in all tissues and from all the locations during the two seasonal harvests. The $\mathrm{Ni}^{2+}$ binds strongly to the gills rendering it less functional. Fishes however, have developed mechanisms to control and regulate their nickel burdens. $\mathrm{Cu}$, like $\mathrm{Ni}$ is essential for enzyme activities, but the divalent $\left(\mathrm{Cu}^{2+}\right)$ state is also biotoxic. Other metals $(\mathrm{Fe}, \mathrm{Mg}, \mathrm{Cr}, \mathrm{Ca}, \mathrm{Na}$ and $\mathrm{K}$ ) investigated, though not present at toxic levels, can pose some threat to the fish tissues through bioaccumulation and biomagnification (WHO, 1992). The concentration of the heavy metals in the tissues may bedependent on the sediment and water concentration. The concentrations will likely increase in future as a result of increased human activities. This can be explained on the basis that some ofthese metals that were held in stagnant stream must have beingchannelled away with floods during rainfall. $\mathrm{Pb}, \mathrm{Cd}, \mathrm{Cr}$, and $\mathrm{Cu}$ featured more prominently during the rainy season sampling from River Gagare. The reason may be that, though River Gagare is a tributary to Goronyo Dam, it may likely be receiving waste discharges from some sources during therainy season.If these wastes contain some heavy metals,they may be incorporated in water bodies and bottom sediment which some fishes feed on. River Rima and Goronyo Dam tissue specimens presented higher $\mathrm{Pb}$ and $\mathrm{Cd}$ valuesin the rainy seasonthanin the dry season. As with River Gagare, floods might have contributed to this increase. Mg appeared in high concentrations in all the locations and in all tissues during therainy season in contrast to Fe that have lower values in the same season. The reason for lower $\mathrm{Fe}$ level may be due to the fact that some tissues have bioaccumulated $\mathrm{Pb}$, and $\mathrm{Pb}$ displaces $\mathrm{Fe}$ in some enzyme reactions, causing anaemia.

We appreciate the assistance of laboratory staff of Departments of Agriculture and Biochemistry,Usmanu Danfodiyo University, Sokoto, Nigeria. The chief Technologist, Department of Analytical Chemistry, Sheda Science and Technology Centre (SHESCO) Abuja, in whose company the metal analysis was carried out is also acknowledged.

\section{References}

[1]. Baron MG (1995). Bioaccumulation and Biomagnification in Aquatic Organisms In: Handbook of Ecotoxicology pp 652-662. (Hoffman DH, Rattner BA, Burton BA Jr, Cairns GA Jr. Eds). CRS Press Inc- Lewis Publishers. London. Tokyo. Pp $652-662$.

[2]. Davis CA, Tomlinson K, Stephenson T (1991). Heavy metals in River Tees Estuary Sediments. Environ Technol.186: 961-972.

[3]. Duncan RC., Knapp RG., and Miller MC (1997). Test of hypothesis in population means. In: Introductory Biostatistics for health sciences. John Wiley and Sons Inc. NY pp 71-76.

[4]. Don -Pedro OP(1997). Differential Responses of Perenial Salt Masch Plants to Oil Pollution. Ph.D Thesis Imperial College of Science and Technology University of London. pp 258 FAO/WHO (1993). World Health Organization Report of the 36th Session of the Codex Committee on Food Additives and Contaminants. 28th session. The Hague, Netherlands. p 22-24 Tfp://fop.org/codex/ccfac38/fa3:18e.pdf cited 15thJune 2011.

[5]. FMH (2010). Federal Ministry of Health. Zamfara state lead poisoning epidemic. In: US CDC Report June 2010.

[6]. Goyer RA (1991). Toxic Effects of Metals. In Amdur M.O., Doull, J.D., and Klaasen C.D. (Eds). Casarette and Doull' Toxicology 4th ed. Pergamon Press. New York pp 625-680.

[7]. Keen CL, Leornard BO, Fisher GL (1981). Age- Related Variation in Hepatic Iron, Copper, Zinc and Selenium Concentrations in Beagles. Am J. VetRes. 42: 1884-1887.

[8]. Kiffhey PM, Clement WH (1994). Effects of Heavy Metals on a Macrovetebrate Assemblage from a Rocky Mountain Stream in Experimental Microcosms. J. AmBent Soc. 13: 511-523.

[9]. Lane TW, Morel FMM (2000). A Biological Function in Marine Diatoms. Procedures inNat. Acad of Sci. 9: 4627-4631.

[10]. Largerweff JN (1972). Lead, Mercury, and Cadmium as Environmental Contaminants. In JJ Mortredt PM, Giodano WL, Lindsay P. Eds. Micronutrients in Agriculture. Soil Sci Soc Am. Madison. 50: 593- 636.

[11]. Moore JW, Sutherland DJ (1991). Distribution of Heavy Metals and Radionucleotides in Sediments, Water, and Fish in an Area of Great Lake Contaminated with Mine Wastes. Archivesof Environmental Contamination and Toxicology. 10: 329-338.

[12]. Mouvet C (1984). Accumulation of Chromium and Copper by Aquatic Moss, Fontinalis antipyretica 1. ex Hedu Transplanted in a Metal Contaminated River.Environmental TechnologyLetters. Moore J.W (1991). Inorganic Contaminants of Surface Water. New York: Spring Verlag 5: 541-548.

[13]. Nordberg K (1972). Fish Mercury Distribution in Massachusetts USA Lakes. Environmental Toxicology and Chemistry.18: 13581389.

[14]. ReddyKJ, Wang L, Gloss SP (1995). Solubility of Copper, Zinc, and Lead in Acidic Environment. Plant and Soil. 171: 53-58. 
[15]. Stewart EA, MaxGrimshaw H, John AP, Christopher Q (1974). Chemical Analysis of Ecological Materials. Institute of Terrestrial Ecology. Merlewood Research Station, Grange -Over- Sands, Cumbria. pp 97.

[16]. Venugopal B, Luckey TP (1975). Toxicology of non-radioactive heavy metals and their salts: In Heavy metal toxicity, safety and hormology. TD Luckey, B Venugopal, D Hutchenson (Eds). George Theime, Stuttgart. pp 85.

[17]. Weast B (1998). Heavy metal distribution in different fish species from the Mauritanian coast. Science Total Environment. 232: $169-175$

[18]. Whiteside, PJ (1987). An Introduction to Atomic Absorption Spectrophotometry. Published by Pye Unican Ltd, First Edition. pp 25

[19]. WHO (1992). World Health Organization. Report of the $36^{\text {th }}$ session of the Codex Committee on Food Additives and Contaminants, Rotterdam, The Netherlands, 22-26, March. pp

[20]. WHO (2011). World Health Organization. Lead poisoning recorded in 43 Nigerian villages. A report from United Nations Public Health Arm. pp 22 